\title{
15
}

\section{Elephants in the Kitchen: Responding to the Challenge of Rapidly Changing Climate and Land Use}

Brendan Mackey

\section{Key Points}

- The impacts of human-forced climate change will continue to be felt for millennia, irrespective of our success or failure to mitigate greenhouse gas emissions.

- Therefore, climate change adaptation must be understood as a 'forever' activity and mainstreamed in policy, planning and decision-making.

- In parallel, we are witnessing unprecedented land use change in terms of extent and intensification that is transforming the land surface, together with subsurface processes, in ways as profound as climate change.

- Policies and programs that aim to reduce emissions of greenhouse gases from the land sector will continue to be a key component of Australia’s response to its Paris Agreement commitments.

- We have the data and information to address these emerging pressures; however, we lack the public understanding, political will and national policy to require their use. 
- State and territory governments must take the necessary step change. There is a need for national leadership by the Australian Government if the new generation of data, knowledge products and decision support tools are to be developed, and the policies that drive their application in support of agreed national land use goals put in place.

\section{Introduction}

An elephant in the kitchen, or any other room for that matter, is an idiom for an obvious problem that no one wants to discuss. Here, I discuss some elephants that public policy currently ignores: the synergistic effects on the land sector of climate change and land use change, and the implications for ecologically sustainable development. I then consider the kind of data, information products, decision support tools and policy responses that are needed if we are to have the informed land use planning and management that these problem warrant.

The extent to which climate change presents profound risks to the economy has been on the record at least since the work of William Cline (1992) and, more popularly, since the Stern (2006) review, which estimated that without mitigation, the costs would be equivalent to losing 5-20 per cent of global GDP each year (i.e. US\$3.9-\$15.6 trillion in 2014), now and forever, versus around 1 per cent of global GDP each year to avoid harm (i.e. US\$0.8 trillion in 2014) (World Bank, 2015). From the public sector perspective, more recent estimates suggest that 6 degrees Celsius of warming represent present-value losses worth US $\$ 43$ trillion, which is about 30 per cent of the entire stock of the world's manageable assets (Economist Intelligence Unit, 2015). These economic statistics point to the magnitude of the problems we face in all sectors, including land sectors, in mitigating emissions and adapting to a rapidly changing climate.

The land sector is multifaceted when it comes to climate change. It functions as both a source of emissions and a sink; terrestrial ecosystems naturally exchange carbon dioxide with the atmosphere and intensive land use depletes organic carbon stocks. About 27 per cent of the total accumulated anthropogenic greenhouse gas emissions are from the land sector (compared with 35 per cent from coal); they constitute about 10 per cent of current annual global emissions, and there is still about four times the atmospheric stock of carbon remaining in terrestrial ecosystems 
(Global Carbon Project, 2014; Mackey et al., 2013). However, the land is also the place where people live, harvest fresh water and grow most (90 per cent) of their calorie intake (with aquaculture, freshwater and marine fisheries supplying about 10 per cent) (Nellemann et al., 2009). Climate change also affects the functioning of natural, semi-natural and agro-industrial systems, with implications for species, including invasive species ecosystems and agricultural productivity (Intergovernmental Panel on Climate Change [IPCC], 2014).

\section{Climate Change is 'Forever'}

The idea of the effects of climate change being 'forever', as implied by the Stern review, is scientifically valid. Due to the extraordinarily long atmospheric lifetime of a pulse of carbon dioxide, together with lag effects in the Earth system (especially the oceans), the impacts of human-forced climate change will continue to be felt for millennia, irrespective of our success or failure to mitigate greenhouse gas emissions (Mackey et al., 2013). However, this is not to say that we should abandon efforts to mitigate greenhouse gas emissions. Deep cuts in emissions are required to meet the Paris Agreement (United Nations, 2015) commitment to holding the increase in the global average temperature to well below 2 degrees Celsius above pre-industrial levels, and pursuing efforts to limit the temperature increase to 1.5 degrees Celsius above pre-industrial levels. Conversely, a business-as-usual approach could lead to increases of more than 6 degrees Celsius as we enter the twenty-second century (Brown \& Caldeira, 2017). Notwithstanding our success or failure to mitigate, climate change adaptation must be understood as a 'forever' activity and mainstreamed into policy, planning and decision-making at all levels of governance and in all sectors. The prospect of continuously changing climate impacts also has significant implications for data management, as it implies ongoing monitoring and adaptive management responses in light of new information.

\section{Land Use Change is Unprecedented}

In parallel with rapid human-forced climate change, we are witnessing unprecedented land use change in terms of the rapid extension of modern economic activities onto previously natural lands, and the intensification 
of land use through agro-industrialisation (Goldewijk, Beusen, Van Drecht \& De Vos, 2011). This rapid land use change is being catalysed by a combination of financial, globalisation and technological innovations, as we witness a national increase in agro-industrial and mining enterprises of increasing magnitude. Examples include coal seam gas mining (Australian Broadcasting Commission, 2012), coalmining (Department of State Development, 2015) and irrigated farming schemes (Department of Agriculture and Fisheries, 2015). Further indications of the land use changes that lie ahead are articulated in the White Paper on Developing Northern Australia, and the new National Water Infrastructure Development Fund that, in addition to accelerating investment in water infrastructure, has more than $\$ 5$ billion available for other forms of infrastructure-much of which will directly or indirectly support land use change in the region (Australian Government, 2015).

\section{The Low Carbon Economy}

To stabilise atmospheric concentrations of greenhouse gases at a level that gives a greater than 50 per cent chance of limiting warming to below 2 degrees Celsius above pre-industrial levels, only about an additional 1,000 gigatons of carbon dioxide $\left(\mathrm{CO}_{2}\right)$ can be emitted; this amounts to about 30 years' worth of current annual global emissions (IPCC, 2013). Given the deep cuts needed in emissions to meet this target, it is not surprising that a range of mitigation policy approaches are being explored, including market-based mechanisms. Carbon pricing mechanisms currently exist in around 40 countries, including emission trading schemes, carbon taxes, payments for emission reductions and the purchase of offsets (Economist Intelligence Unit, 2015; World Bank, 2016). While the concept of a comprehensive global carbon market is appealing in theory, it is unlikely in practice. The most likely scenario is that the 'bottom-up' approach underpinning the Paris Agreementwhereby each country makes nationally determined emission reduction commitments and employs mitigation approaches and policies that are tailored to national circumstances-will continue. The result, for better or worse, will be a diverse policy landscape in which some jurisdictions have a carbon price on certain emissions, but not others; a cohort of jurisdictions will have no carbon price on any emissions, but may have some international linking of carbon pricing mechanisms and continued trading of offsets consistent with the provisions of the Paris Agreement. 
Given the Paris Agreement commitment to holding the increase in the global average temperature to well below 2 degrees Celsius above preindustrial levels, and pursuing efforts to limit the temperature increase to 1.5 degrees Celsius above pre-industrial levels, the pressure is now on to reduce emissions from all sources, including the land sector, which is especially significant for Australia's national greenhouse gas accounts. Australia's 2012 fossil fuel emissions were 31 per cent above its 1990 levels; however, when land use, land use change and forestry are included, total emissions had only increased by 2.4 per cent. The difference arises because emissions can be deducted, in accounting terms, by 'withdrawals' from the atmosphere into ecosystems; land sector credits offset 28.6 per cent of Australia's industrial emissions over this period. Given the significance of the land sector to Australia meeting mitigation reduction targets, we can anticipate that the land sector will face ongoing and new pressures generated from Australia's Paris Agreement commitments.

In addition to carbon credit-generating activities, such as afforestation, reforestation and avoided emissions through conservation, new agricultural enterprises are already emerging to service the low carbon economy. Biofuel is now mandated at some level in around 64 countries, including the European Union (EU) (which has mandated 5-7.5 per cent renewable content by 2020), 13 countries in the Americas, 12 in the Asia-Pacific region, 11 in Africa and the Indian Ocean and two from non-EU countries in Europe. Global demand will be affected by targets set in the United States, China and Brazil; these countries have set targets in the 15-25 per cent range by 2020-22 (Biofuels Digest, 2014). Another emerging, and potentially disruptive, industry is biomaterials made from bio-based or bio-derived polymers from natural renewable resources, such as corn, soy, potatoes and sugar cane, rather than petroleum feedstocks (PolyOne, 2008).

Demands for new land uses to service the low carbon economy will be driven by a combination of public policy, such as national mitigation reduction targets, and private investments. These demands will compete with existing land uses, especially food production, for fertile land, water and capital. The synergistic effects of a rapidly changing climate and new land uses promise to be highly economically, ecologically and socially disruptive, with prospects for surprises and unplanned feedback in what is, from a scientific perspective, a non-linear and complex socio-ecological system. 


\section{Data, Information and Decision Support}

The kinds of land use problems we face are becoming increasingly complicated due to the synergistic interactions of climate change, technological innovation, influx of foreign capital (Sanyal, 2014) and new land-based economic activities, such as coal seam gas and biofuels. Fortunately, at all three levels of government, Australia has made great advances in land-related data and its online availability, including data on surface and groundwater resources, natural hazards, remotely sensed land cover and high-resolution continental soil grids (e.g. Terrestrial Ecosystem Research Network, 2015). We also have ready access to the world's most advanced current and future climate data, including regionally scaled projections (Commonwealth Scientific and Industrial Research Organisation, 2015; Department of Premier and Cabinet, 2015).

However, there remains a gap in processing many of the available data into information products that are useful for policy and decision-making, such as catchment condition assessments (e.g. Worboys, Good \& Spate, 2011). Further, decision-making in a climate-changed world requires more sophisticated approaches, such as the use of scenario modelling to help identify policy options that are robust under plausible alternative futures, which can account for accumulated and long-term impacts on our scarce water and fertile soil resources, among other things.

However, we face a more fundamental problem than lack of the right information and decision support tools. Land development policies and proposals continue to be rolled out without proper reference to the available data and information, and large-scale industrial developments are being approved where the data and system understanding needed for sustainability planning are known to be lacking. The states and territories have conventionally been primarily responsible for planning and land management. It follows that current failures should be laid primarily at their feet, rather than with the Australian Government. Nonetheless, the Australian Government has external affairs powers that enable it to give effect to international treaty obligations through national policy, along with powers over interstate trade, commerce and corporations. To give effect to Australia's obligations under relevant international conventions, including the UNFCCC, the Convention on Biological Diversity and the Convention on Wetlands (known as the Ramsar Convention), measures need to be taken concerning land use management. 
The Australian Government has an acknowledged role in helping to coordinate and harmonise state and territory government policies regarding matters that serve the national good. These arrangements are often negotiated at the Council of Australian Governments and facilitated through non-coercive means such as grants. The water resources sector shows how national objectives can be advanced on natural resource management issues; although some problems remain, the states reached an agreement with the Australian Government. The Australian Government used its constitutional powers, including external affairs, to enact the Water Act 2007. This Act established the Murray-Darling Basin Authority, which has the functions and powers, including enforcement powers, needed to help ensure that Basin water resources are managed in an integrated and sustainable way. Given the pressures on the Australian landscapes from the imperative to mitigate greenhouse gas emissions, disruptive influences of emerging land use activities and impacts of a rapidly changing climate, among other things, such cooperative arrangements will be needed in the coming years.

\section{Recommendations}

We have unprecedented data, information and decision support tools available for improved land use decision-making at all levels of government. Information communication technology (ICT) is making astonishing advances with high-performance computers, mass-data storage and internet connectivity approaching transformational thresholds. Now is the time to consolidate our excellent progress, take advantage of emerging ICT capacities and generate the kinds of advanced information and decision support needed in the coming decades for ecologically sustainable land use policy, planning and management.

However, in the absence of both a broader base of recognition of the seriousness and urgency of these problems and their significance for longterm ecological sustainability and a corresponding surge in the political will, it is unlikely that the investment of funds needed to drive this step change in capacity will be forthcoming. While state and territory governments must take on the required step change themselves, there can be no doubt that the Australian Government has a leadership role to play. This role could be realised through the collaborative formulation of 
a national land use strategy that drives the development of the required data, information products and decision support tools, and requires their application at all levels of government to meet agreed land use goals.

\section{References}

Australian Broadcasting Commission. (2012, 28 June). The coal seam gas rush. $A B C$ News Online. Retrieved from www.abc.net.au/news/ specials/coal-seam-gas-by-the-numbers/

Australian Government. (2015). Our north, our future: White paper on developing northern Australia. Canberra, ACT: Australian Government. Retrieved from northernaustralia.gov.au/files/files/ NAWP-FullReport.pdf

Biofuels Digest. (2014, December 31). Biofuels mandates around the world: 2015. Biofuels Digest. Retrieved from www.biofuelsdigest.com/ bdigest/2014/12/31/biofuels-mandates-around-the-world-2015/

Brown, P. T. \& Caldeira, K. (2017). Greater future global warming inferred from Earth's recent energy budget. Nature, 552, 45-50. doi.org/10.1038/nature24672

Cline, W. R. (1992). The economics of global warming. Washington, DC: Institute for International Economics.

Commonwealth Scientific and Industrial Research Organisation. (2015). Climate change in Australia. Canberra, ACT: Department of Environment and Bureau of Meteorology. Retrieved from www.climatechangeinaustralia.gov.au/en/

Department of Agriculture and Fisheries. (2015). Flinders Gilbert agricultural zone. Retrieved from www.daf.qld.gov.au/business-trade/ development/industry-development/flinders-gilbert-agricultural-zone

Department of Premier and Cabinet. (2015). Climate futures for Tasmania. Retrieved from acecrc.org.au/climate-futures-for-tasmania/

Department of State Development. (2015). Carmichael coal mine and rail project-project overview. Retrieved from www.statedevelopment. qld.gov.au/assessments-and-approvals/carmichael-coal-mine-and-railproject.html 
Economist Intelligence Unit. (2015). The cost of inaction: Recognising the value at risk from climate change. Retrieved from www. eiuperspectives.economist.com/sites/default/files/The $\% 20 \operatorname{cost} \% 20$ of\%20inaction_0.pdf

Global Carbon Project. (2014). Global carbon budget 2014-an annual update of the global carbon budget and trends. Retrieved from www. globalcarbonproject.org/carbonbudget/index.htm

Goldewijk, K. K, Beusen, A., Van Drecht, G. \& De Vos, M. (2011). The HYDE 3.1 spatially explicit database of human-induced global land-use change over the past 12,000 years. Global Ecology and Biogeography, 20,73-86. doi.org/10.1111/j.1466-8238.2010.00587.x

IPCC (Intergovernmental Panel on Climate Change). (2013). Summary for policymakers. In T. F. Stocker, D. Qin, G.-K. Plattner, M. Tignor, S. K. Allen, J. Boschung, A. Nauels, Y. Xia, V. Bex \& P. M. Midgley (Eds.), Climate change 2013: The physical science basis (Section E.8 p. 27). Cambridge, UK: Cambridge University Press.

IPCC. (2014). Summary for policymakers. In C. B. Field, V. R. Barros, D. J. Dokken, K. J. Mach, M. D. Mastrandrea, T.E. Bilir, ... L.L. White (Eds.), Climate change 2014: Impacts, adaptation, and vulnerability (Part A: Global and sectoral aspects) (pp. 1-32). Cambridge, UK: Cambridge University Press.

Mackey, B., Prentice, I. C., Steffen, W., House, J. I., Lindenmayer, D., Keith, H. \& Berry, S. (2013). Untangling the confusion around land carbon science and climate change mitigation policy. Nature Climate Change, 3, 552-57. doi.org/10.1038/nclimate1804

Nellemann, C., MacDevette, M., Manders, T., Eickhout, B., Svihus, B., Prins, A. G. \& Kaltenborn, B. P. (Eds.). (2009). The environmental food crisis: The environment's role in averting future food crises [GRIDArendal website]. Retrieved from www.grida.no/publications/154

PolyOne. (2008). Biomaterials development in the polymer industry (Technical Bulletin). Retrieved from www.polyone.com/files/ resources/Biomaterials_Development_in_the_Polymer_Industry.pdf

Sanyal, K. (2014). Foreign investment in Australian agriculture (Research Paper Series 2013-14). Canberra, ACT: Department of Parliamentary Services. 
Stern, N. (2006). Stern review on the economics of climate change. London, UK: HM Treasury.

Terrestrial Ecosystem Research Network. (2015). Terrestrial Ecosystem Research Network. Retrieved from www.tern.org.au/

United Nations. (2015). The Paris agreement. Retrieved from unfccc. int/files/essential_background/convention/application/pdf/english_ paris_agreement.pdf

Worboys, G. L., Good, R. B. \& Spate, A. P. (2011). Caring for our Australian Alps catchments (Technical Report). Canberra, ACT: Department of Climate Change and Energy Efficiency.

World Bank. (2015). Gross domestic product 2014. World Development Indicators database, World Bank. Retrieved from databank.worldbank. org/data/reports.aspx?source=world-development-indicators

World Bank. (2016). Pricing carbon. Retrieved from www.worldbank.org/ en/programs/pricing-carbon 
This text is taken from Land Use in Australia: Past, Present and Future, edited by Richard Thackway, published 2018 by ANU eView, The Australian National University, Canberra, Australia.

doi.org/10.22459/LUA.02.2018.15 